\title{
LANGUAGE EDUCATION IN LEGAL COMMUNICATION
}

\author{
Kathrin Sotrel, Izabela Grzywacz, Aleksandra Hasiak, Aleksandra Pec \\ University of Warsaw, Poland
}

k.sotrel@student.uw.edu.pl, i.grzywacz@student.uw.edu.pl, a.hasiak2@student.uw.edu.pl, am.pec@student.uw.edu.pl

Mentor: Joanna Osiejewicz

University of Warsaw, Poland

j.osiejewicz@uw.edu.pl

\begin{abstract}
The article analyses the potential influence of language education on legal communication. This work is divided into subsections, each devoted to a specific aspect of the matter. First of all, the paper discusses various features of language used in legal discourse. Also, it provides the reader with examples of mistakes that could be avoided by changing the vocabulary and sentence structures. Furthermore, the work discusses the obstacles that the migrants encounter due to the lack of suitable terminology used in legislation. The paper aims to offer solutions which linguists may introduce to improve the transparency of legal communication.
\end{abstract}

Keywords: language education, legal communication, language transparency, terminology errors, legal texts.

\section{INTRODUCTION}

The today's society is provided with extraordinary access to information. Based on the above, it could be expected that both individuals and the whole communities would be well-educated, at least regarding matters which significantly affect their everyday life. Unfortunately, nothing could be further from the truth. The increased availability of information often results in unwillingness or simply not feeling the need to gain new knowledge. Of course, not every human being has to be an expert in a variety of fields; nonetheless, as far as basic legal aspects are concerned, it is highly recommended to be aware of the rights and obligations to which every citizen is entitled. To quote the old adages: Ignorantia legis neminem excusat and Ignorantia iuris nocet (Eng. ignorance of law excuses no one and not knowing the law is harmful, respectively).

However, it should be also taken into account that the society's unwillingness is not the most substantial issue in this context. Particular attention should be paid to the language used by jurists, as their vocabulary is usually noticeably formal. Furthermore, they often employ convoluted sentence structures. For this reason, most of the phrases might not be fully understandable to an average person without any legal background. When certain 
matters are beyond the comprehension of a human being, loss of interest is a normal reaction, yet in terms of legislation it can have severe consequences for the individual.

In order to encourage the public to acquaint themselves with basic legal aspects, the problem connected with their lack of interest should be addressed at the source. Therefore, it is imperative that lawyers be taught about the significance of conveying clear messages in their statements.

\section{MATERIALS AND METHODS}

The method we have applied in this work is the content analysis method of diverse Polish and foreign authors' articles, of the reference sources and of the examples used to illustrate the differences between individual words and phrases.

The primary objective was to reiterate the necessity and the usefulness of educating lawyers in the matter of using lucid language. We also wanted to demonstrate the main possible risks generated by using immensely sophisticated vocabulary that might be misleading to people without legal training.

\section{RESULTS AND DISCUSSION}

\section{The specific character of legal language and difficulties related to it}

In order to better comprehend the key analysis of this paper, one should focus on the language per se beforehand. As a law theorist, Bronisław Wróblewski claims there is a distinction between the legal language and the lawyer's language (1948). The former term refers to the language that is used for creating legislation, e.g. regulations or statutes, whereas the latter concept encompasses communication among lawyers - applying and interpreting law. Interestingly enough, such a distinction is merely observable within the Polish culture (Bukowska-Pelc, 2017).

In legal language, similarly to any other professional language, precision constitutes a feature of utmost importance. Therefore, legal texts are constructed based on formal logic. In other words, they need to be as provable as mathematical theorems. This condition, however, is not always obeyed, which generates misunderstandings due to increased ambiguity. It may result from the fact that among all the professional languages, legal language is considered to be the one with the greatest polysemy (Pieńkos, 1999). Another feature that does not help while interpreting legal texts is the high level of abstractness of legal norms (Bukowska-Pelc, 2017).

Urszula Bukowska-Pelc in her article "Precyzja języka prawnego jako przykład precyzji języka fachowego" enumerates difficulties that arise in legal texts, which highly disturb the perception. She mentions that within one legal order a given term may appear with various meanings, depending on an area of law (Bukowska-Pelc, 2017). This, in turn, severely affects the interpretation. Moreover, one can often observe borrowings and technical terms, which should not be a part of a good text of this kind (Wronowska \& Zieliński, 2012). As Urszula Bukowska-Pelc notices, much of ambiguity may stem from an "incorrect way of 
constructing legal definitions, i.e. vicious circle of definition, defining the unknown by the unknown, or definition irrelevance" (2017). The above-mentioned errors severely disrupt the transparency of the language.

\section{The role of linguists in language education}

These difficulties, however, could be significantly lessened through the contribution of linguistics to legal communication. Joanna Osiejewicz names a couple of improvements which this dynamically developing field may introduce (2021).

To begin with, linguists have peculiar language skills that enable them to construct explicit statements effortlessly. Due to this fact, they can help lawyers to create transparent messages. Jurists often use complicated constructions unknowingly, which may appear unintelligible for the majority of society. This, in turn, causes difficulties in the communication between lawyers and people lacking legal education.

Furthermore, attention must be given to shaping communication awareness among the public; they should know that it is their right to demand articulate statements from lawyers. It may be challenging to convince a person with legal education that they speak a language that is ambiguous to non-professionals. Also, the lawyers are often convinced that their statements cannot be constructed in any other way since that is what they were taught. In other words, they do not realize that it is possible to communicate in a less convoluted manner. However, if linguists make efforts to create this kind of awareness among society, it may translate into significant improvement in the communication between these groups.

Another relevant aspect in the role of linguists is conducting research that would show the significance of legal communication. Unfortunately, this field still remains unexamined. Moreover, both scientific studies and empirical research, which focuses on effective legal communication, may play an essential role. These empirical studies would help with gathering information in the field of judicial proceedings, as well as of witnesses' behaviour in a courtroom, i.e. in-depth analysis of specific conventions.

Also, linguists may work on theoretical research and terminology applied in the legal profession. It is known that terms used by lawyers exhibit universality. On the one hand, this is why legislation does not require constant changes, as the terms remain valid. On the other hand, this could e.g. confuse judges who may find certain terms misleading. Therefore, the involvement of linguists in legal communication is of utmost importance, as they could help in framing terminological knowledge.

Additionally, legal education, which is primarily based on substantive issues, should be extended by linguistic research. It would undoubtedly make the work of lawyers more efficient. The inherent component of legal education is the matter of communication, thus teaching within this sphere should be assigned to linguists.

\section{Remarks on education with regard to intergenerational communication}

In order to communicate effectively with clients, lawyers should be taught by linguists to consider differences between age groups and adjust their language to various generations: Generation of the economic crisis of the 1930s, Baby Boomers, Generation X, Generation Y and Generation Z. If the distinguishing characteristics of different generations are disregarded, lawyers and their clients may misunderstand each other. There is a chance that the client's 
competences are inadequate and therefore they might not be able to understand the lawyer (Osiejewicz, 2021). Also, generations vary in terms of the preferred communication style, key technology, hobbies, and digital proficiency. Members of each generation require a different message form (Osiejewicz, 2020).

According to Joanna Osiejewicz, during conversations with the Generation of the economic crisis of the 1930s, lawyers should use such terms as we, us in order to gain their trust. Questions concerning their needs and statements such as I respect your experience may also be appreciated. Regarding Baby Boomers, lawyers have to provide them with simple facts and options that will help them make decisions. Their questions should be answered both precisely and by the use of positive wording. Short stories and appreciative phrases as we need you might be helpful. With regard to Generation X, again, simple facts are useful. Lawyers should also use direct, unthreatening language, e.g. you are different, we respect that. Generation Y requires using dynamic verbs and nouns that may help them imagine certain circumstances. For instance, in place of defendant, lawyers could say Kowalski. Finally, while talking with Generation Z, lawyers should use visualisation. Instead of explaining complicated processes, it would be beneficial to show simple schemes. Generation $\mathrm{Z}$ wants their needs to be met instantaneously, therefore phrases such as as soon as possible might be useful (Osiejewicz, 2020). In order to better illustrate the need to adjust language to a particular age group, here is an example of article 42 from Convention on the Rights of the Child in original (1989): "States Parties undertake to make the principles and provisions of the Convention widely known, by appropriate and active means, to adults and children alike" and in Child Friendly Language: "You have the right to know your rights! Adults should know about these rights and help you learn about them, too" (Osiejewicz, 2021)

\section{The significance of terminological education}

The equitable use of language plays a crucial role not only in a lawyer-client relationship, but it also affects daily lives of whole communities. Unfortunately, the world is still missing proper language education in foreigners' affairs. In practice, it is still challenging to differentiate between the terms immigrant in an irregular situation and refugee, although it is legally recognised that these two expressions do not apply to each other.

Joanna Markiewicz-Stanny in her article "Language of normative acts and social exclusion of immigrants in irregular situation" portrays the severe position of immigrants in the modern world which is significantly influenced by terminology. As the author states, "Terms such as prohibited, illegal and deportable give an extremely wide scope for imagining what serious violations of the law a foreigner has committed" (2017, p. 98). This demonstrates that the use of such words often leads to biased perceptions and unfair judgements. It shall be required to use words like irregular or non-documented. The lack of education in this area harms multiple communities by shaping their negative attitudes towards immigrants. They instantly and undoubtedly associate such a person with potential risk or danger. Nonetheless, thanks to much research and many observations made on this subject the situation in the European Union has improved. Presently, more neutral words are used since language should not violate human dignity.

However, not only stigmatisation is a problem among immigrants and refugees. Another severe educational deficiency in foreign affairs concerns euphemisation. An alarming 
amount of it is present i.e. in the terminology used by states to describe places of detention of migrants in order to fulfil migration procedures. In such facilities, migrants are isolated from the rest of society. They are under surveillance and the buildings themselves do not differ in appearance from prisons, as they consist of many cells and high walls ended with barbed wire. "During migration procedures in some countries, e.g. in Japan and the USA, measures such as those applied to persons guilty of criminal offences are used, i.e. isolation rooms, strong restraints, handcuffs" (Markiewicz-Stanny, 2017, p.101). Due to lack of education concerning terminology related to migrant facilities, human rights of many people are violated. They experience inhumane conditions. More to it, the nation is not aware of their position. According to Flynn:

Many of these facilities' names reveal contradictory official attitudes: Turkey has called its migrant detention centres guesthouses; Mexico uses migratory stations (estaciones migratorias) for the temporary housing (alojamiento temporal) of migrants; Hungary has guarded shelters, Italy has welcome centres (centri di accoglienza), and France has centres of administrative retention (centres de rétention administrative) (Flynn, 2013, p.7).

Adequate education in terminology plays an essential role in this case since the incorrect use of even one word can spread harm, as shown in the examples above.

\section{Methods for avoiding textual inaccuracies}

Richard C. Wydick in his book "Plain English for Lawyers" describes in detail various types of mistakes made by lawyers in their unintelligible statements. He introduces solutions that may help them avoid sophisticated vocabulary and convoluted sentence structures. Wydick distinguishes and delineates rules which lawyers should follow in order to keep their language coherent.

The first guideline concerns omitting surplus words (Wydick, 2005). In general, there are two types of words: working and glue ones. “(...) [The former] carry the meaning of the sentence. (...) [The latter] hold the working words together to form a proper, grammatical sentence" (Wydick, 2005 p.7). Sentences should be short, contain the minimum amount of glue words and be abundant in working words. For instance, the sentence The ruling by the trial judge was prejudicial error for the reason that it cut off cross-examination with respect to issues that were vital can be changed to The trial judge's ruling was prejudicial error because it cut off cross-examination on vital issues (Wydick, 2005, p.8-9). Additionally, compound constructions, word-wasting idioms and supervacaneous legal expressions should be avoided. For example, prior to may be replaced by before; he was aware of the fact that by he knew that and alter or change by last will and testament (Wydick, 2005, p.11-18). Nominalizations, which are common among lawyers and bureaucrats, are also redundant. Instead of saying make assumptions, it is recommended to use a base verb and say assume.

Moreover, it may be helpful to apply active voice rather than passive voice, and thus shorten the sentences to avoid ambiguity. The next rule concerns arranging words carefully. Lawyers have to remember that in order to make their writing clear, they should not apply wide gaps between the subject, the verb and the object. For example, the sentence This agreement, unless revocation has occurred at an earlier date, shall expire on November 1, 2012 is less understandable than Unless sooner revoked, this agreement expires on November 
1, 2012 (Wydick, 2005, p.42). Also, a valuable practice would be creating a list in place of a lengthy paragraph.

Furthermore, it is worth noting that sentences are often problematic to understand as they contain multiple modifiers. Instead, some of the information could be put in a separate sentence. Modifiers may also cause ambiguity, thus they should be used reasonably. For instance, the sentence endangered frogs and salamanders may be confusing, because the reader does not know if both frogs and salamanders are endangered. Therefore, it can be replaced by endangered frogs and endangered salamanders (Wydick, 2005, p.52).

Additionally, a proper choice of vocabulary items is crucial. Clients may prefer concrete words rather than abstract ones. It is also advised to express thoughts in simple terms, without using lawyerisms such as aforementioned (Wydick, 2005 p.58). The next step includes avoiding enumeration of similar words which could be replaced by just one. For example, in the sentence Every person who...overdrives, overloads, drives when overloaded, overworks, tortures (...) is guilty of a crime...(Wydick, 2005 p.61) the verbs may be replaced by abuse. Another guideline suggests not using language quirks that can easily distract the client.

Last but not least, lawyers must not forget about the proper punctuation. Otherwise the interlocutor might misunderstand them, which can lead to severe consequences (Wydick, 2005).

\section{CONCLUSION}

Thanks to the analysis we have accomplished, the following conclusions can be drawn:

language education in legal communication is indispensable, both concerning lawyers and individuals without any legal background;

lawyers should be familiarised with various ways of conveying their messages in an understandable way;

ordinary people should be taught that they have the right to demand clear statements and precise explanations of legislation.

The proper communication concerning legal matters requires language education among the society. This can only be achieved by way of linguists who would raise awareness in terms of the importance of unambiguous communication.

Legal speech is inherently complex, thus it is natural that the average person might not be familiar with it. Therefore, lawyers should be aware of this fact and attempt to decrease language barriers between them and their clients. Simultaneously, linguists should teach people without any legal background that they do not have to fear asking questions and demanding clear explanations regarding legal matters. Applying all of these recommendations might significantly improve communication and protect innocent people from harm caused by inconsistencies in the terminology of legislation. 


\section{REFERENCES}

Bukowska-Pelc, U. (2017). Precyzja języka prawnego jako przykład precyzji języka fachowego. Lingwistyka Stosowana, 24(4), 37-43.

Flynn, M. (2013). Hidden Costs of Human Rights: The Case of immigration Detention. Global Detention Project Working Paper No 7. https://www.globaldetentionproject.org/wp-content/uploads/2016/06/ flynn_hidden_costs_gdp_working_paper.pdf

Markiewicz-Stanny, J. (2017). Język aktów prawnych a ekskluzja społeczna imigrantów w sytuacji nieregularnej. Lingwistyka Stosowana, 24(4), 95-107. http://alp.uw.edu.pl/wp-content/uploads/ sites/315/2018/10/LS-24-8-Joanna-Markiewicz-Stanny.pdf

Osiejewicz, J. (2020). Komunikacja prawnicza. Prostym językiem o prawie. Wydawnictwo Naukowe Instytutu Komunikacji Specjalistycznej i Interkulturowej Uniwersytet Warszawski.

Osiejewicz, J. (2021, February 24). Zagadnienia wstępne. [seminar].

Osiejewicz, J. (2021, March 31). Komunikacja prawnik-klient. [seminar].

Pieńkos, J. (1999). Podstawy juryslingwistyki. Język w prawie - prawo w języku. Oficyna Prawnicza Muza SA. UN General Assembly. (1989). Convention on the Rights of the Child. United Nations. Treaty Series. 1577. 3. https://www.refworld.org/docid/3ae6b38f0.html

Wronkowska, S., \& Zieliński, M. (2012). Komentarz do zasad techniki prawodawczej z dnia 20 czerwca $2002 r$. Wolters Kluwer.

Wróblewski, B. (1948). Język prawny i prawniczy. Polska Akademia Umiejętności. Wydick, R. C. (2005). Plain English for Lawyers. Carolina Academic Press. 